\title{
The Importance of Power Distance in Students' Social Skills towards Revolution of Industry 4.0 Learning
}

\author{
Meidawati Suswandari ${ }^{1}$, Siswandari $^{2}$, Sunardi $^{3}$, Gunarhadi $^{4}$ \\ \{meidawatisuswandari@student.uns.ac.id ${ }^{1}$, siswandari@staff.uns.ac.id ${ }^{2}$,nardi_ip@uns.ac.id ${ }^{3}$, \\ gunarhadi@fkip.uns.ac.id $\left.{ }^{4}\right\}$ \\ ${ }^{1,2,3,4}$ Sebelas Maret University Surakarta, Indonesia
}

\begin{abstract}
Abstarct. The involvement of student and teacher activeness must not take the rights of each other (power distance) to get the opportunity to build their own knowledge so as to gain deep understanding. This research aimed to describe the importance of power distance as an effort to increase students' social skills toward the revolution of industry 4.0 learning. The research method was a literature study by gathering a number of books, papers, journals, leaflets, and magazines relating to the problem of the power distance on Hofstede's academic culture and social skill. They were then analysed using descriptive analysis, content analysis, and critical analysis. The findings describe that the realization of social skills through the relationship of learning in the classroom between teacher-student or student-student relationship. The involvement of the student and teacher activeness that doesn't take each other's rights in the classroom learning process means that there is no distance between the teacher and students and students with students in the classroom learning that has socially educative interaction. This is the main challenge and task of the teacher in harmonizing the development of the revolution of industry 4.0 in classroom learning.
\end{abstract}

Keywords: power distance, social skill, revolution of industry

\section{INTRODUCTION}

Social skills are part of social competence. Social competence consists of three constructs, namely social adjustment, social performance, and social skills. Social competence itself is a person's ability to establish diplomatic relations with others, both friends and unknown people. Social adjustment is defined as one's success in adjusting himself/herself to other individuals in general and to the group in particular [1]-[3] .

On the other hand, social performance is one's behaviour (especially which can change the environment) in interacting with others, which produces a good result, such as willingness to help others even though they themselves experience difficulties and are not bound to themselves [1], [2], [4]. For a child, social skills and competencies are essential factors for 
starting and having positive social relationships. Children, who do not have social skills and are judged by their peers as those without social competence, will have difficulty in starting and establishing positive social relations with their environment. They may even be rejected and ignored by their environment [5].

Embodiment of social skills is through the relationship of classroom learning between teacher-student or student-student interactions. The involvement of student and teacher activeness does not take the rights of each other to get the opportunity to build their own knowledge so as to gain deep understanding. This leads to Hofstede's principle of power distance which means that there is no gap or distance that differentiates one to another between teacher's rights and student's rights in the classroom learning process.

There is no distance between the teacher and students and students with students in the classroom learning that has socially educative interaction. Social educative interaction is the key to all social lives because without it there would not be possible joint life. In social life, students also need others. The forms of good social interaction can be seen by the existence of cooperation, mutual respect and appreciation. Cooperation is increasingly established when students are happy to discuss with and help each other solve problems in learning faced. Good social interaction between the students can also create mutual respect and create a comfortable atmosphere in learning and will encourage them to excel in the school environment. Therefore, the role of teacher to students is one of the determinants of the success of education [6]-[9].

The role of the teacher in the success of education can be realized through effective learning. Effective learning is creating active learning that empowers students to achieve their competencies. Active learning is student-centred learning that emphasizes students to be active in the teaching and learning process. The shift in teaching style from teacher centre to student centre can certainly increase students' learning interest. The use of information and communication technology in learning into learning innovation has a positive impact. Likewise, the positive impact is also expected from the emergence of the revolution of industry 4.0 in elementary classroom learning.

The term revolution of industry 4.0 comes from a project initiated by the German government to promote computerization of manufacturing. It began from the revolution of industry $1.0,2.0,3.0$, to 4.0 . The industrial phase is a real change of the existing. The revolution of industry 1.0 is characterized by the production mechanization to support the effectiveness and efficiency of human activities. The revolution of industry 2.0 is characterized by mass production and quality standardization. The 3.0 is characterized by mass adjustment and flexibility of automation and robot-based manufacturing. The revolution of industry 4.0 subsequently replaced the revolution of industry 3.0, which was characterized by physical cyber and manufacturing collaboration [10]-[12].

Nowadays, the fourth (4.0) revolution of industry changes the economy, work, and even society itself. The core of the revolution of industry 4.0 is the incorporation of physical and digital technology through analytics, artificial intelligence, cognitive technology, and the Internet of Things (IoT) to create digital companies that are interrelated and capable of producing more informed decisions.

Lee et al explained that the revolution of industry 4.0 was marked by an increase in digitalization of manufacturing driven by four factors: 1) increased data volume, computing power, and connectivity; 2) the emergence of analysis, capability, and business intelligence; 3) the occurrence of new forms of interaction between humans and machines; and 4) improvement of digital transfer instructions to the physical world, such as robotics and 3D printing [13]. Lifter and Tschiener added that the basic principle of the revolution of industry 
4.0 is the integration of machines, workflows, and systems, by applying intelligent networks along the chain and the production process to control each other independently [14].

Today's human position in Indonesia is disrupted or uprooted. In the past, we waited for public transports to go somewhere, and then came taxis. After taxis mushroomed, online vehicles came up like Go-jek and Go-car. People used to come to a traditional barber to shave. Now, a modern and practical barbershop industry has emerged [15].

The revolution of industry 4.0 is a tough challenge for Indonesian teachers. Education and learning full with knowledge content put aside the content of attitudes and skills as currently implemented, which will produce students who are not able to compete with machines [16], [17]. Therefore, the challenge for teachers is to create social skills towards the revolution of industry 4.0 without any power distance between teachers and students and and between the students themselves.

\section{METHOD}

The research method was the literature study by gathering a number of books, papers, journals, leaflets and magazines relating to the problem of learning models in students. The data were collected by identifying books, papers or articles obtained. The data analysis used descriptive analysis, content analysis and critical analysis. Descriptive analysis is collecting and compiling data based on library sources which is then analysed. Content analysis is utilizing a set of procedures in drawing conclusions from several documents that have been obtained. On the other hand, critical analysis was carried out by interpreting the text and responding it based on the literature study.

\section{RESULTS AND DISCUSSION}

\subsection{The Low level of Social Skills}

Based on the data of preliminary observations at Sukoharjo elementary schools with a sample of 3 elementary schools namely SDN Palur 4, SDN Kamal 1, and SDN Gayam 2 Sukoharjo, 7 (35\%) out of 20 students showed mastery of social skills in the good category. 13 students $(65 \%)$ are not good at mastering social skills in the class. This is similar to the cooperation between students in groups (25\%), helping each other $(20 \%)$, and expressing and listening to opinions $(25 \%)$. Some other attitudes that show low social skills include: some students do not know their friends who are absent (30\%) and do not lend rulers and erasers to others $(15 \%)$. In addition, almost all clever students choose to work on the questions independently when the teacher asks them to discuss $(80 \%)$ and the students have the lack of academic competition during learning (20\%).

The Role of Industrial Revolution 4.0 in Learning

The low level of social skills is the main task of a teacher in creating educative interaction socially through power distance towards the revolution of industry 4.0. According to Palo Alto Group [18] there are two types of social skills that appear in the form of interaction patterns in the role of the teacher in creating social skills towards the revolution of industry 4.0 without any power distance between teachers and students and between the students. The first type is if two people respond to one another in the same way, they are said to be involved in a symmetrical relationship. The second type is complementary relationship. In this connection, the communicator responds in the opposite way. When one is dominating, others obey it; when he is argumentative, the other is silent; when he maintains, others accept it. 
In the learning process, interaction patterns can occur between teachers and students, between the students, students and learning resources, and students and the environment. Furthermore, the circle of relationships between communicators is what builds communication interactions. Anwar stated that learning will create a two-way communication pattern. In this situation, the teacher and students can change their position as an element of communication. The teachers can sometimes become a communicators and the students become communicants, but under other conditions it can be the opposite [2], [3], [8], [19].

The research findings are one of the preparations that can be used to deal with the rapid flow of globalization in the revolution of industry 4.0 era. Through learning, the teacher is expected to be a model and example for students so that eventually they are expected to be prepared in such a way as to be able to compete and collaborate well through effective communication. Learning that refers to the concept of two-way communication is 'the relationship of sending and receiving messages between communicators and communicants' in the learning process' the relationship of sending and receiving messages between elements of learning: teacher-student, student-teacher, and student-student [18].

\subsection{The Importance of Power Distance in Students' Social Skills}

Two-way learning has mutual relationship between teachers and students and between the students without any distance that the teacher is considered someone who is frightening and tends to dominate learning. Power distance teaches students to get their rights to get the comfort and effectiveness from the teacher or others. Their position is not considered lower than others. Likewise, they do not have power and control over each other even in collaborative activities in groups. The group leader is not the most dominating object in the group, but each other gets the same right to express ideas, opinions, suggestions, and criticisms in the learning process.

The existence of students without a gap between students and teachers, students one with other students is part of the power distance to learning in the industrial revolution 4.0. On the one hand, we need to know students experience the development stage as the next generation towards the conditions expected in the industrial revolution 4.0. According to Mannheim, generation is a group consisting of individuals who have similarities in the age range and experience important historical events in the same time period. Tapscott in his book entitled "Grown Up Digital" divides the demographics of the American population into several generations of groups as follows:

a. The Baby Boom (born between 1946 - 1964).

b. The Baby Bust or Generation X (born between 1965 - 1976).

c. The Millennial or Generation Y (born between 1977 - 1997).

d. Generation Net or Generation Z (born between 1998 and now).

Mc Crindle added that after generation Y in 2010, the Alpha generation was born. All the generations are combined and described in the following chart [20]. 


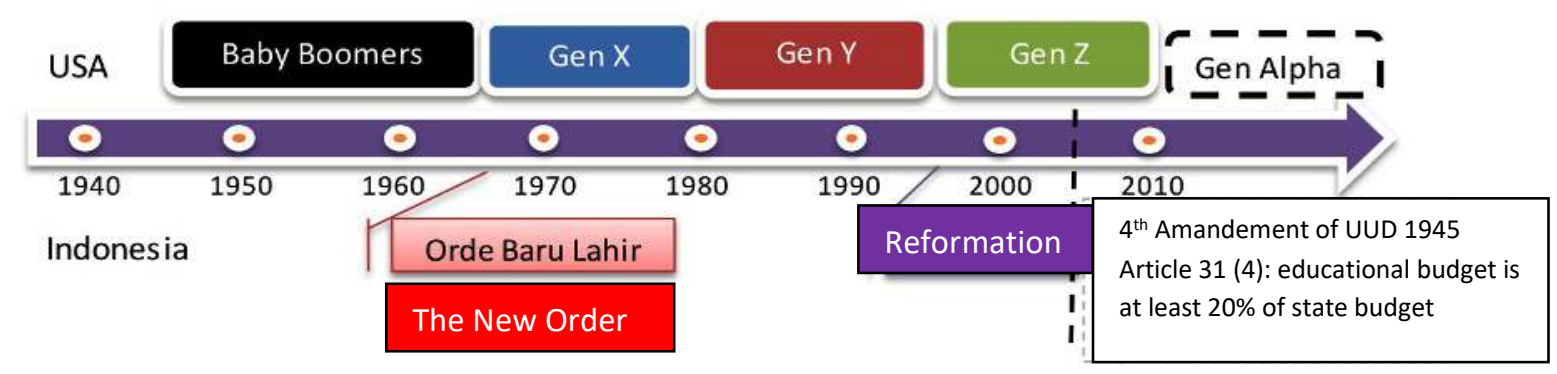

Chart 1. Time Line Generation

Current student development is in the Alpha Genes zone that measures student involvement in critical, creative, innovative learning processes. The learning of the Alpha Genes zone is through Power distance in two-way communication. Two-way communication is the answer of the existence of the revolution of industry 4.0 to strengthen teachers in implementing innovative learning in improving students' social skills. Although the industrial revolution 4.0 is focused more on the digital learning process, social skills also become the main key to being able to maintain the students' social skill aspect. Teacher's efforts through improving innovative learning include life-based learning (LBL) to prepare students who are ready to face the challenges of their time. The student identity is established as a complete human being who has capabilities with continuous development pattern. Life-based learning is the process of acquiring knowledge and skills, understanding the nature of life, being skilled at solving problems in life, and living a balanced and harmonious life. Life-based learning puts forward the concept that learning from life is real learning [21] [22].

\section{CONCLUSION}

The involvement of student and teacher activeness does not take the rights of each other to get the opportunity to build their own knowledge so as to gain deep understanding. This leads to Hofstede's principle of power distance which means that there is no gap or distance that differentiates one to another between teacher's rights and student's rights in the classroom learning process. There is no distance between the teacher and students and students with students in the classroom learning that has socially educative interaction. This is the main challenge and task of the teacher in harmonizing the development of the revolution of industry 4.0 in classroom learning.

\section{REFERENCE}

[1] N. A. Kauffman and M. Kinnealey, "Comprehensive social skills taxonomy: Development and application," Am. J. Occup. Ther., vol. 69, no. 2, 2015.

[2] S. Rahmah, M. A. Jamal, and S. Suyidno, "Meningkatkan Keterampilan Sosial Siswa Melalui Penerapan Pembelajaran Kooperatif Tipe Teams Games Tournament," Berk. Ilm. Pendidik. Fis., vol. 2, no. 1, p. 55, 2018.

[3] M. Daraee, K. Salehi, and M. Fakhr, "Comparison of Social Skills between Students in Ordinary and Talented Schools,” no. March, pp. 512-521, 2016.

[4] M. Janah, "Peningkatan Keterampilan Sosial Peserta Didik SMA Menggunakan Layanan Bimbingan Kelompok Dengan Teknik Diskusi Laila Maharani, Hardiyansyah Masya," vol. 05, no. 1, pp. 65-72, 2018. 
[5] S. Rina and Akhbariansyah, "Meningkatkan Profesionalisme Guru Dalam Menghadapi," pp. 713-724, 2019.

[6] H. Anttila, K. Pyhalto, J. Pietarinen, and T. Soini, "Socially Embedded Academic Emotions in School," J. Educ. Learn., vol. 7, no. 3, p. 87, 2018.

[7] B. Pappas, C. Caponecchia, and E. H. Wertheim, The Human: Principles of Social Interaction. 2012.

[8] G. De Giorgi et al., "Understanding Social Interactions: Evidence from the Classroom," 2013.

[9] T. Hao and L. Huang, "A social interaction activity based time-varying user vectorization method for online social networks," IJCAI Int. Jt. Conf. Artif. Intell., vol. 2018-July, pp. 3790-3796, 2018.

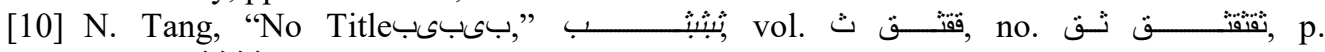
ثقتقتق 2018.

[11] C. Hart, S. Warburton, and B. Westera, "De prinses en de pakjes," e-Tech J. Ilm. Teknol. Pendidik., vol. 6, no. 2, 2019.

[12] A. Supriatna, "Kegiatan Lesson Study sebagai Upaya Guru untuk Menemukan Pembelajaran yang Memenuhi Keperluan Anak Hidup pada Zamannya (Era Revolusi Industri 4.0)," Edusainstek, vol. 1, no. 1, pp. 1-5, 2018.

[13] H.-C. Pfohl, B. Yahsi, W. Kersten, T. Blecker, and C. M. Ri, "The Impact of Industry Supply Chain," Proc. Hambg. Interrnational Conf. Logist., no. December, pp. 31-58, 2015.

[14] M. YAHYA, "Era Industri 4.0: Tantangan dan Peluang Perkembangan Pendidikan Kejuruan Indonesia," 2018.

[15] Hamidulloh Ibda, "JRTIE: Journal of Research and Thought of Islamic Education Vol. 1, No. 1, 2018," vol. 1, no. 1, pp. 1-21, 2018.

[16] H. Suwardana, "Revolusi Industri 4 . 0 Berbasis Revolusi Mental," vol. 1, no. 2, pp. 102-110, 2017.

[17] Hamdan, "Industri 4.0: Pengaruh Revolusi Industri pada Kewirausahaan Demi Kemandirian Ekonomi," vol. 3, no. 2, pp. 1-8, 2018.

[18] J. Nagy, J. Ol, and E. Erdei, "The Role and Impact of Industry 4 . 0 and the Internet of Things on the Business Strategy of the Value Chain - The Case of Hungary," 2018.

[19] N. Mohd, M. Hakimie, Z. Abidin, A. Yazid, and A. Bakar, "Dimensions of social skills and their relationship with empathy among gifted and talented students in Malaysia," Procedia - Soc. Behav. Sci., vol. 116, no. 2003, pp. 750-753, 2014.

[20] S. R. Retnaningdyastuti, "Tantangan dan Peluang Siswa dan Guru BK Di Era Disrupsi," Pros. Semin. Nas., pp. 6-12, 2018.

[21] H. Subekt, M. Taufiq, H. Susilo, I. Ibrohim, and H. Suwono, "Mengembangkan Literasi Informasi Melalui Belajar Berbasis Kehidupan Terintegrasi Stem Untuk Menyiapkan Calon Guru Sains Dalam Menghadapi Era Revolusi Industri 4.0: Revieu Literatur," Educ. Hum. Dev. J., vol. 3, no. 1, pp. 81-90, 2018.

[22] K. Saddhono and D. Sulaksono, "Indoglish as adaptation of english to Indonesian: change of society in big cities of Indonesia." IOP Conf. Ser.: Ear. and Envi. Sci.. vol. 126 no. 1 IOP Publishing, 2018. 